LET: Linguistics, Literature and English Teaching Journal

||Volume||11||Issue||1||Pages||61-87||2021\|

|P-ISSN: 20869606; E-ISSN: 25492454|

Available online at: http://jurnal.uin-antasari.ac.id/index.php

\title{
DEVELOPING TEACHERS' PEDAGOGICAL COMPETENCE THROUGH ENGLISH SUBJECT TEACHERS' WORKING GROUP (MGMP)
}

\author{
Haliza \\ lilisa1907@gmail.com \\ Hidayah Nor \\ hidayahnortbiuin@gmail.com \\ Nani Hizriani \\ nanihizriani@gmail.com
}

Antasari State Islamic University of Banjarmasin, Indonesia

\begin{tabular}{|c|c|}
\hline Article History: & $\begin{array}{l}\text { This study is aimed to determine how is the } \\
\text { contribution of English Subject Teachers' }\end{array}$ \\
\hline Received: 27 April 2021 & Working Group (MGMP) in developing teachers' \\
\hline Accepted: 12 June 2021 & pedagogical competence and how the teacher's \\
\hline Corresponding Author: & in this study was descriptive qualitative. The data \\
\hline & was collected through interview and \\
\hline Tel.: & documentation. The result showed that the English \\
\hline hidayahnortbiuin@gmail.com & MGMP gave a good contribution to the \\
\hline Keywords: & $\begin{array}{l}\text { competence. The contribution of the MGMP in } \\
\text { developing teachers' pedagogical competence }\end{array}$ \\
\hline Subject Teachers' Working & was carried out through the involvement of \\
\hline Group (MGMP); Contribution; & $\begin{array}{l}\text { various parties and MGMP programs itself. The } \\
\text { result of this study also showed that the English }\end{array}$ \\
\hline Teachers; Perception; & teachers gave a positive perception on the \\
\hline Pedagogical Competence & $\begin{array}{l}\text { contribution of MGMP in developing teachers' } \\
\text { pedagogical competence. The teachers considered } \\
\text { that the MGMP as a community gave a big } \\
\text { contribution in developing their competence. }\end{array}$ \\
\hline
\end{tabular}

Haliza

LET: Linguistics, Literature and Language Teaching Journal Vol. 11 No. 12021 


\section{INTRODUCTION}

Teaching profession is a very important profession in the life of a nation. Teachers are the dominant element in an educational process, so that the quality of education is largely determined by the quality of educators in carrying out their roles and duties in society. Therefore, increasing the professionalism of teachers is a very basic and important thing to improve the quality of education. The efforts to develop the professionalism of teachers continue to be developed in order to be able to perform its functions optimally.

Nuraida and Nurteti (2018) also mentioned that new developments in the view of teaching and learning have consequences for teachers to increase their roles and competencies because the teaching and learning process and student learning outcomes are largely determined by the role and professionalism of teachers. The role and professionalism of teachers in the teaching and learning process includes many things, including the role of instructors, class leaders, mentors, planners, motivators, counselors, etc. Professional teachers will be better able to manage their class so that student learning outcomes are at the optimal level (p. 72).

Referring to the Indonesia's Law of Teacher and Lecturers No.14 (2005) stated that as a professional teacher must master four competencies in carrying out their duties. The four competencies are pedagogical competence, personal competence, social competence and professional competence. Of the four competencies, pedagogical competence is a competence that is the main focus and attention in improving teacher ability. This is because pedagogical competence is basic competence and become the foundation for teachers to be able to do their main task, which is teaching.

The development of pedagogical competence is something that must be the center of attention for a teacher in order to be able to carry out his/her roles and duties effectively and efficiently. Therefore, the development of teachers' pedagogical competence needs to be done so that teachers always have an open attitude and follow positive new developments in education world. Basically, the 
development of teachers' pedagogical competence is to add insight or knowledge, improve skills, and inspire enthusiasm in teaching. This is reinforced by the explanation in the same Law, Chapter IV Section 34, Subsection 1, that: "The government and regional governments must foster and develop academic qualifications and teacher competencies in education units organized by the Government regional governments and / or the community".

Various efforts to develop the quality of learning have been carried out, both by the government and by various parties who care about learning. These various efforts include in the form of: 1) upgrading; 2) teacher education qualifications; 3) curriculum renewal; 4) implementation of new learning models or methods; and 5) research on students' difficulties and mistakes in learning or what teachers often do such as classroom action research (Tedjawati, 2011, p. 480). In addition, according to Marno and Idris (2010), they said that developing teachers' competencies can be done in various ways such as: further education, in service training, the formation of forums for improving the quality of teachers such as Supervision, Pemantapan Kerja Guru (PKG), and Musyawarah Guru Mata Pelajaran (MGMP) (p. 27).

Teachers are just ordinary people who are not free from mistakes or negligence. Therefore, teachers need to develop and improve their ability to carry out their professional duties. In answering these problems, a special teacher organization was formed, namely activities carried out by teachers in the same field of study or commonly called as MGMP. MGMP is a place for collaborative teachers to gather in a certain area (Regency / City) in order to identify and solve problems, try and develop new ideas in order to improve the quality of learning. In addition, a variety of knowledge, experience, and training will be obtained to improve teachers' motivation. Moreover, this forum is believed to be one of the effective media to foster teachers professionalism within the framework of activities by, from and for teachers (Jalal, 2005, p. 55). This statement implies that the MGMP forum is a forum to develop innovation, creativity, communication, consultation, information, and coordination among peer teachers of similar subjects in order to improve the quality of learning. 
English MGMP of vocational high school Kota Banjarmasin is one of MGMP forum in Banjarmasin that is fairly active in carrying out activities and routine meetings. Based on the data and information that the researcher obtained from Mrs. Marlina as the head of English MGMP of vocational high school Kota Banjarmasin, this forum includes 18 vocational high schools and 51 English teachers and 5 administrators consists of the head, secretary, treasurer, sector of professional development, and sector of organizational development. In this MGMP. forum there are programs that aim to increase self-potential, especially for new teachers who have not much experience and senior teachers who have been fixated with KTSP where in the teaching and learning process looks monotonous and lack of understanding in the use of learning tools or media. This forum is held regularly once a month in rotation and sometimes presents speakers to provide material. But unfortunately not all members or English teachers can attend these regular meetings. That is because there are some teachers who clash with the teaching schedule at school because this meeting is held during teaching hours between 09.00-12.00 a.m. Then the lack of funds owned by English MGMP of vocational high school Kota Banjarmasin because there is no financial assistance. In the past, there was indeed a financial assistance from the Education Office, but now there is no more, this is causing the implementation of this forum to be slightly hampered.

In the act of the Republic of Indonesia Number 14 years 2005 states that teachers as professional educators are in charge in educating, teaching, guiding, directing, training, and evaluating students in formal early education (Ada and Azisah, 2016, p. 239). Teachers in carrying out their professional duties are required to have supporting competencies, especially pedagogical competencies. This competency becomes the main point of the task as a teacher because the teacher's role cannot be separated from the activities of educating and teaching students. In teaching, teachers need to have special skills, such as understanding insight or educational foundation, understanding about students, developing curriculum / syllabus, designing learning, implementing learning that educates and dialogues, 
evaluating learning outcomes, developing students to actualize their potential. This needs to be understood in depth by every teacher so that learning can take place effectively (Ada and Azisah, 2016, p. 241).

Teachers are just ordinary people who are not free from mistakes, negligence, or forget. Therefore, teachers need to develop and improve their ability to carry out their professional duties. In answering these problems, a special teacher organization was formed, namely activities carried out by teachers in the same field of study or commonly referred to as MGMP. The establishment of the MGMP aims to facilitate teachers in developing teacher competencies, specifically pedagogical competencies. So, teachers in the same field of study meet and gather together to discuss ideas, information, subject matter, and problems that are being experienced to be solved and sought the right solution. Then MGMP is very useful for teachers as a place to develop teacher competencies in a smaller scope, namely at the city or district level.

Furthermore, MGMP has several activities that can be carried out to achieve the objectives of developing and improving teacher competencies. In MGMP there are three programs, namely general programs, core programs (routine and development programs), and supporting programs.

Of the three programs, there are programs that are often carried out and routine in each MGMP with the activities carried out, as follows: (a) Discussion of learning problems; (b) Preparation and development of syllabi, semester programs and learning program plans; Curriculum analysis; (c) Preparation of student learning outcomes reports; (d) deepening of the material; (e) Training related to the mastery of material that supports teaching assignments; (e) Discussion of material and stabilization to face the National Examination and School Examination. Apart from these activities, there are also other activities that are included in the general program, development, and also support, but are given only occasionally and not too often. This is related again to the funds owned and also the parties carrying out development activities. The activities carried out in the MGMP are expected to be able to broaden insights and knowledge for teachers in various ways, especially in 
the implementation of the learning process; Provide opportunities for teachers to share experiences to provide mutual assistance; Improve the knowledge and skills needed; Developing teacher professionalism in order to guarantee the quality of education; Develop mentoring and sharing activities between senior and junior teachers.

There are several previous studies related to MGMP forum in developing teacher competences. Rodhi (2015) in his journal focusing on the organization structure of English Subject Teachers' Working Group of senior high school and the capacity the of the forum in promoting teacher professional development (TPD). The conclusion obtained from this study is that the capacity and function of the English MGMP in Kota Pontianak were not maximally utilized to promote TPD as a result of being unwell managed in terms of management and membership, schedule of activities, and program coverage, as well as the result of inadequate support from educational institutions in terms of monitoring of MGMP activities and management.

Purnomo (2015) investigated the correlation of teachers' participation in English MGMP of junior high schools in Purwakarta sub-district towards professional competence of teachers. This research is a quantitative research using two variables, namely teacher participation in English MGMP and professional competence of English teachers. The subjects of this research are English teachers with a population of 14 teachers. The sampling technique uses saturated sampling technique. This is because the relatively small population is less than 30 people. The data were collected through questionnaire. The results of this research indicate a positive and significant correlation between teacher participation in the MGMP forum and teachers professional competence.

Anugerahwati and Saukah (2010) conducted a research entitled "Professional Competence of English Teachers in Indonesia: A Profile of Exemplary Teachers". This research aims to find out the profile of exemplary English teachers in secondary schools. This research was conducted in four cities, included exemplary teachers in one senior high school and three junior high 
schools. The subjects were exemplary in terms of their active participation in the MGMP forum, and their role in the professional development of both themselves and their colleagues. The data were collected through observation, interviews and questionnaires which subsequently analyzed qualitatively by the usual process of sorting, coding and analyzing. The findings produce that the subject teachers in three of the four cities had all four competencies (professional, pedagogical, social and personal competencies), with the personal competencies being the most influential in forming them as professional and exemplary teachers. From the findings of the professional competency profile of the exemplary English teachers in secondary schools is developed.

Mulatsih (2016) investigated the role of MGMP in developing teachers' pedagogical competence. The main issues discussed in this study are the role of the MGMP in developing PPKn teachers' pedagogical competence and what obstacles arise in the role of the MGMP to develop teachers' pedagogical competence. The data were collected through observation, interviews, and documentation. The results of this study indicate that the role of the MGMP in developing teachers' pedagogical competence includes: discussing and developing learning materials, regular discussions on developing issues related to learning, holding dialogues with outsiders / expert teachers / education experts in the field of PPKn, as well as holding study tours to develop teacher insights, and conduct training. The obstacles faced by the MGMP in developing teachers' pedagogical competence include: inadequate meeting schedules, some members do not carry out activities in accordance with the activity implementation schedule program, the management's unpreparedness for internal problems regarding problems that must be resolved, the absence of control and evaluation.

The similarity between this researches with the previous researches are both conducting research in the Subject Teachers' Working Group (MGMP). The differences between this research and the previous researches, specifically Mulatsih's research, she focused on the role of the MGMP forum in improving teachers' pedagogical competence and what obstacles arise in the role of the MGMP 
forum. Whereas in the current research, the writer focussed on the contribution of the English Subject Teachers' Working Group (MGMP) of Vocational High School in Kota Banjarmasin in developing teachers' pedagogical competence and how are teachers' perceptions on English MGMP forum in developing their pedagogical competence.

From the explanation above the researchers are interested in conducting the research related to the contribution of the MGMP forum in developing English teachers' pedagogical competence of vocational high school in Kota Banjarmasin.

\section{METHOD}

This research employed a qualitative approach. This study was conducted in English MGMP of Vocational High Schools in Kota Banjarmasin. The English MGMP included all English teachers of Vocational High Schools in Kota Banjarmasin, both public and private, where there are 18 vocational high schools and 51 English teachers and 5 administrators consists of the head, secretary, treasurer, sector of professional development, and sector of organizational development. For the specific place, actually there was no specific place for every meeting in the MGMP forum. Each meeting alternately in every vocational high school in Kota Banjarmasin in accordance with a predetermined schedule. English MGMP of vocational high school Kota Banjarmasin is one of MGMP forum in Banjarmasin that is fairly active in carrying out activities and routine meetings. This is the reason why researcher chose the MGMP forum as the place of the research.

\section{Method of Collecting Data}

The researchers collected the data by interview, and documentation. This interview method was chosen to obtain information about how the contribution of the English MGMP forum in developing teachers' pedagogical competence, and how are the English teachers' perceptions on that contribution in developing their pedagogical competence. The documentation method was chosen by the researcher to collect data about the organizational structure of English MGMP of vocational 
high schools in Kota Banjarmasin, the decree, the MGMP programs, and data about the teachers participating in English MGMP of vocational high schools in Kota Banjarmasin.

\section{Method of Analysis Data}

To answer the first research question related to the contribution of MGMP in developing teachers' pedagogical competence, the researcher refers to the theories from MGMP guidelines (Depdiknas, 2004) and Sutrisno (2009). Meanwhile, to answer the second research question related to the teachers' perception on the contribution of MGMP in developing teachers' pedagogical competence, the researcher refers to the theories from Mushfah (2011), Jalal (2005), Leu (2004) and Villegas-Reimer (2003).

Data analysis technique in this research was Interactive Model of Analysis. As stated by Miles and Huberman (1994) analysis during the field consists of 3 components of data analysis namely data reduction, data display and conclusion drawing/verification (p. 60, cited in Sugiyono 2014).

\section{Data Reduction}

Data reduction is a form of analysis that sharpening, classifying, directing, discards unnecessary, and organizing the data in such a way that the final conclusions can be drawn and verified. In this stage, the researcher carried out the data analysis process by examining all the data, both interview and documentation. After that, the researcher focused on what data needed regarding the contribution of MGMP in developing teachers' pedagogical competence and reduced the data that was not relevant to the research.

\section{Data Display}

After the first stage, the researcher analyzed the data by presenting some data findings from interview and documentation in narrative form. Miles and Huberman (1994) stated that the most frequent form of data display has been used for qualitative is narrative form. By displaying the data, it made the researcher

\section{Haliza}


easier to understand what happened, to plan further work based on what was understood.

Conclusion Drawing/Verification

The third stage in qualitative data analysis was conclusion drawing/ verification. In this stage, the researcher carried out conclusion drawing/ verification continuously throughout the research process, namely from the beginning of the research to the data collection process regarding the contribution of MGMP.

\section{FINDINGS AND DISCUSSIONS}

\section{Findings}

The Contribution of English Subject Teachers' Working Group (MGMP) in Developing Teachers' Pedagogical Competence

Parties Involved in the Activities of English MGMP of Vocational High School Kota Banjarmasin in Developing Teachers' Pedagogical Competence

The researcher got the data by interviewing 9 teachers. The findings showed that the contribution of English MGMP in developing tachers' pedagogical competence through MGMP activities was carried out by involving various parties. Usually the parties involved in developing teacher pedagogical competences based on the theme of activities carried out. This is because the activities were adjusted to the resource persons who have expertise in providing material for the activities. The English MGMP of Vocational High School Kota Banjarmasin usually collaborated with various parties from outside such as from several universities in Banjarmasin. This finding reinforced by the teacher from the interview results, she said:

“...biasanya kita juga sering bekerjasama dengan Universitas-universitas seperti ULM, jadi universitas tersebut bisa membantu meng-update kemampuan,teknologi, dan strategi-strategi baru yang ada diluar sana sehingga kita bisa lebih terekspose dengan hal-hal baru”.(appendix 3)

Haliza 
(Usually we often collaborated with several universities such as ULM, so the university can help and update capabilities, technologies, and new strategies that are out there so that we can be more exposed to new things).

The explanation above was strengthened by one of the teachers /members of the English MGMP, she said that usually MGMP had invited external speakers, for example lecturers from ULM, UIN which was in accordance with the theme of the MGMP activities carried out. In addition, there was an explanation by another teacher which provided reinforcement from the previous explanation, he said that MGMP had given a significant role in the development of teachers' pedagogical competences by often invited external speakers, both from lecturers and experts who are connected to English learning.

Furthermore, the administrators and the members of MGMP also often share about their teaching experiences, things they have gotten from seminars, training or other experiences. This is reinforced by the teacher from interview results, the teacher said "kami sering sharing tentang metode-metode yang memang bisa diterapkan di kelas, misalnya metode apa yang digunakan saat mengajar speaking, sering juga sharing mengenai media mengajar bagaimana penggunaannya”. (We often share about methods that can be applied in classroom, for example what methods are used when teaching speaking, we also often share about teaching media, how to use them).

Moreover, that was also reinforced by the explanation from another teacher, he mentioned that the administrators and the members of MGMP had shared about media, an interesting digital application for students. They share their teaching experiences when using application such as Instagram app. So, the teachers who do not know how to use the application as learning media ultimately become know.

The parties involved apart from the administrators and members of the MGMP and various external parties, were also supervisors and advisors from Dinas Pendidikan dan Kebudayaan Provinsi Kalimantan Selatan. This is consistent with the result of the interview obtained from the head of the MGMP, she said 
“...sekarang ini di MGMP terdapat Pengawas Pembina dari Dinas Pendidikan dan Kebudayaan Provinsi Kalimantan Selatan, dengan pengurus inti yakni Ketua, Sekretaris dan Bendahara". (Currently, in the MGMP, there were Supervisors from Dinas Pendidikan dan Kebudayaan Provinsi Kalimantan Selatan, with the core board, namely the head, secretary and treasurer). This explanation was later strengthened by another teacher, he said "biasanya MGMP mengundang pihak dari dinas pendidikan dan kebudayaan, jadi mereka memberikan insight (pemahaman), dan bertukar pikiran juga”. (Usually MGMP invited the parties from Dinas Pendidikan dan Kebudayaan, so they provide insight, and exchange ideas as well).

Intensively, the development of the pedagogical competence of English teachers in the MGMP is more often carried out by the administrators and members of the English MGMP. This is in accordance with the interview results, the teacher said "Kalau dulu sebelum pandemi kegiatan di MGMP setiap bulan ada. Biasanya sharing pengalaman mengenai perangkat baik itu cara mengajar jadi kita sharing di MGMP. Intinya meningkatkan kemampuan kita mengajar”. (Before the pandemic, there were activities at the MGMP every month. Usually sharing experiences about the tools, both how to teach, so we share in the MGMP. The point is to improve our ability to teach). Furthermore, this was reinforced by the teacher from interview results, she said that basically their concept in MGMP was that apart from working together, they also share with each other, for example problem they faced when teaching in the classroom, so later if the members have an idea or have a way to solve it, they can share it at MGMP.

Thus, the English MGMP activities to develop teachers' pedagogical competence were carried out intensively by the administrators and members of the English MGMP, although there were often collaborations with various parties to deliver material according to the objectives to be carried out.

Programs and Activities of English MGMP of Vocational High School Kota Banjarmasin Related to the Development of Teachers' Pedagogical Competence

Haliza 
English MGMP of Vocational High School Kota Banjarmasin Work Program that available is just in 2017/2018 (appendix 7). The work program used as data is only taken from 2017/2018 because the work program for 2019/2020 is not yet available.

Regarding the MGMP activities carried out in 2017/2018, it can be seen that the activities for the development of teacher competency, especially pedagogical competence, have not been specifically scheduled. Usually, when it comes to material that will be discussed at the MGMP meeting, it will be adjusted to the willingness of the resource person. In addition, usually MGMP activities related to the development of teachers' pedagogical competence can be carried out by sharing among members who have gained experience in an education and training or workshop, which is then disseminated to other MGMP members.

From the data in the table and the data attached to it, it can be seen that there are several activities related to the development of teachers' pedagogical competence that have been carried out. The following is an explanation of the implementation of the activities that have been carried out based on the data the researcher got from the interviews and documentation:

Sharing Material on How to Make Learning Module

The purpose of this activity was to help and facilitate the teacher in learning process and deliver messages to students to make it more effective and efficient. During the implementation of this activity, the MGMP presented a speaker from the English Language lecturer FKIP ULM, Dr. Cayandrawati Sutiono, MA. She shared about how to make a good and correct English learning module. After the discussion was carried out, the teachers became more aware of the stages of making English learning modules properly and correctly.

Sharing Material from the Finalist of Olimpiade Guru Nasional (OGN)

The purpose of this activity was to share knowledge and experiences by teachers who have participated in OGN. The teacher who had participated in the OGN was Mrs. Nurul Mawaddah S.Pd. She is an English teacher at SMKN 4 
Banjarmasin. The teacher shared about various things such as what she faced during OGN, what had to be prepared, and the "Best Practice" she used during the OGN final. Best Practice is the teacher's written work that contains the best experiences in the learning process. One of the "best practice" she shared was when she was learning with an online system. So students were given a task to post their photos on Instagram using English captions. In addition to sharing knowledge and experiences between teachers, this kind of activity can also provide motivation for other teachers to join OGN later.

\section{Sharing How to Make ICT-Based Learning Media}

The purpose of this activity was to help teachers understand and improve their abilities in teaching and learning process using IT, such as creating media in the form of digital applications. MGMP conducted meetings with English teachers in order to provide training for teachers in making media with applications. This activity was delivered by resource persons, specifically MGMP administrators or members who are proficient in IT or even present external resource persons who are not only proficient in learning English but also in technology.

In the activity, the teachers were introduced to various things related to computer and internet, such as how to search for teaching materials via internet and how to create learning media with applications. Some of the applications that have been discussed in the MGMP such as Kahoot, Quizziz, Seesaw and Edpuzzle. After the explanation was done, then the teachers were taught how to use the applications. After the teachers carried out the activity, the teachers can gain knowledge on how to make interesting learning using digital applications.

Sharing of making Soal USBN and Sharing Teaching Strategies by Ms. Liann Camille D. Perez

This activity was carried out to discuss the division of making Soal USBN. In which the teachers are formed in groups to make a grid of questions, questions, and answer keys. After the drafting of the grid and the questions was completed, the MGMP submitted the questions to the MKKS SMK. At that time, the USBN 
questions were equated per district/city, so the MGMP made those questions. This activity also aims to improve the understanding and ability of teachers in arranging grids and questions. Usually the parties that foster this activity is the MGMP administrators themselves.

On the same day, Sharing Teaching Strategies was also carried out. The purpose of this activity was to help teachers understand and improve their ability to convey learning to students. MGMP held this activity in order to provide training for English teachers in delivering or providing learning to students. During this activity, the MGMP presented a resource person, namely Ms. Liann Camille D Perez from Philippines who is proficient in teaching. After this activity was held, the teachers who attended gained more knowledge about the effective English teaching strategies for students, so that they could apply them when they taught in the classroom.

\section{Sharing Pragmatics in English Language Teaching}

The purpose of this activity was to increase the ability or skills of teachers in providing teaching appropriately and correctly. In this activity, MGMP presented FKIP ULM lecturer, Yusuf Al Arief, M. Hum as a resource person. The activity discussed about teacher pragmatics, where it discussed how teachers understand the conditions and situations of students, in order to build good emotional relationships between teachers and students. So not only focus on preparing learning materials, but become more sensitive and empathetic to the students' conditions.

Making Core Competencies (KI) and basic Competencies (KD) Analysis and Lesson Plan of 2013 Curriculum 2017 Revision

The purpose of this activitiy was to increase the understanding and ability of teachers to make lesson plans before they are implemented to students. Usually the resource person was the MGMP administrator itself, but if the MGMP does have funds or is currently collaborating, then there was an external party who is assigned as a speaker. 
In the activity, the MGMP discussed about making of lesson plan which then divided the basic competencies (KD) of the Curriculum 2013 revised 2017 which consisted of 32 combined KD, divided into 3 levels, class X, class XI, and class XII. After the KD distributed, usually the teachers also share to make lesson plan. They work together for maximum results. So after the results are collected, they can adjust or adapt the lesson plan to the conditions in their respective schools.

MGMP programs and activities are usually carried out depending on the needs felt by the teachers, and if the material discussed at the MGMP meeting is adjusted according to the willingness of the resource person. Usually discussions such as the latest information, curriculum, syllabus, and preparing lesson plans are held before the beginning of the school year. This was intended to equalize perceptions among English teachers of Vocational High School. Meanwhile, during the course of the school year, the teachers in the MGMP usually share more often about the things they get from seminars, training or other things.

From the description of several programs and activities that have been carried out above, it can be seen that there were several activities that have never been carried out in the English MGMP forum. Even though these activities can help teachers to be able to develop competencies and improve their abilities. The activities that have never been carried out, such as a comparative study to the English MGMP in other regions. In addition, the English MGMP Kota Banjarmasin have never held a seminar or activity that could attract the attention of many people. This was confirmed by one of the MGMP members, the teacher said it was hoped that later the MGMP can hold activities. Because he saw in Banjarbaru, there were activities that could very well accommodate all teachers, such as holding seminars. So he hope that the Engish MGMP of Vocational High School Kota Banjarmasin can also hold activities like that in order to improve the skills of English teachers. Not only in Banjarmasin but also outside by holding sharing of things like seminars, workshops, or training.

Teachers' Perception on the Contribution of English MGMP in Developing Teachers' Pedagogical Competence 
To find out about the teachers' perception on the contribution of English MGMP in developing teachers' pedagogical competence, the researcher conducted an online interview with some teachers who participated in the English MGMP of Vocational High School Kota Banjarmasin. The researcher interviewed 9 teachers consists of the head, the treasurer, and 7 members of the MGMP forum.

\section{The Head of English MGMP of Vocational High School Kota Banjarmasin}

The teacher felt that the activities carried out at the MGMP forum were very helpful in increasing teacher competence. She said that MGMP as a community made a big contribution to teachers in increasing their competence, be it pedagogic, professional or social, if indeed the MGMP can be active in every routine meeting. She also said that there were many benefits when teachers partisipated in MGMP activities, for example when a teacher passed the Olimpiade Guru Nasional (OGN), and the teacher shared about the Best Practices that she used during the OGN final. It can provide meaningful experiences for members of MGMP, and of course also motivate them to join OGN later. In addition, she also mentioned that in every MGMP meeting, there were resource persons from several universities, such as ULM and STIKIP PGRI Banjarmasin. Then, many topics were discussed during the activities, for example regarding the $K-13$ teaching Method, English Teaching Pragmatism, How to Make Learning Module, Making an Interesting Media for Teaching, Digital Literacy, and most recently since the Covid 19, there was sharing about the applications like Seesaw and Edpuzzle. Thus, she felt that the activities at the MGMP really improved the knowledge and skills of the teachers.

The Treasurer of English MGMP of Vocational High School Kota Banjarmasin

The teacher felt that the activities carried out in the MGMP forum really helped teachers in developing personal and pedagogical competences. She thought that if the English teachers were active in participating in the MGMP activities, it would definitely be beneficial for them. She also said that during the new school year, at the MGMP they discussed the annual program, semester program, effective time, KKM, and about the books that they want to use, etc. In addition, she

\section{Haliza}


mentioned that before the National Examination there were grating operations, making learning media, making lesson plans/learning tools. Therefore, she suggested that teachers participate and be active in every activity in the MGMP forum.

\section{Teacher A}

The teacher felt that the English MGMP is a place for learning. She said that when teachers are busy in their respective schools, it is likely that they will not have time to improve both professional and pedagogical competence. So, the problems they might face at school, they can bring to the MGMP and find ways to handle the problems or find the solutions. Whether it's sharing or hearing from the experiences of other members.

She said that by sharing the experiences, they became more aware of the proper teaching strategies, how to recognize students' psychology, and so on. She strongly suggested that teachers participate in MGMP activities because as far as she knew teachers were obliged to attend MGMP in the subject they were able to do because they had to be registered at the education office.

\section{Teacher B}

The teacher felt that the contribution of the MGMP forum had a very significant impact on each member. He said that when teachers participate in the MGMP activities, they know more about several things because the MGMP presents resource persons who are proficient in education and teaching. They are not only proficient in English but also in technology and information. He also said that they were taught how to use several applications such as Quizziz, Kahoot, etc. In addition, he mentioned that there is one of the members in the MGMP who has attended a lot of training. So the teacher shares with them what she got from the training.

Furthermore, the teacher felt many benefits that he got when participating in the MGMP forum. Regarding the development of pedagogical competence, such as understanding how the students' characteristic, using media and tools, designing

\section{Haliza}


syllabus, designing questions and evaluations, and of course a lot of experience and new knowledge that he got when he active participated in MGMP activities.

\section{$\underline{\text { Teacher C }}$}

The teacher said that the MGMP forum contributed a lot to the development of teacher competencies. The teachers are taught how to make good instructional media, then there are also some parts that they realize when teaching a material they use inappropriate media, so they are taught how to use the right media. Furthermore, she also said that in the MGMP they got a lot of knowledge, such as how to edit interesting learning videos, create game accounts such as Kahoot, Quizziz, which they can use when teaching in the classroom. This is not much different from other teachers' previous statements, she also said that the MGMP programs and activities would be very good if every English teacher was willing to actively participate in every MGMP meeting of Vocational High School Kota Banjarmasin.

\section{Teacher D}

The teacher felt that the English MGMP really helped the teachers and made a good contribution to make English teachers better in teaching. She said that "...hal tersebut dikarenakan para anggotanya diberikan pembekalan untuk menjadi guru yang lebih baik". (it is because the members are provided with training to become good teachers). She also said that she got many benefits when participating in the MGMP activities, such as being able to make better lesson plans by sharing among other MGMP members. Furthermore, she got a lot of knowledge about new learning media which made English lessons more interesting and easier for students to understand.

Teacher E

The teacher felt that there were many contributions in the MGMP forum in developing teacher competencies. She said "Dari MGMP para anggota mendapatkan ilmu dan informasi yang sangat bermanfaat dari kegiatan yang diadakan maupun informasi yang diberikaan. Di MGMP juga ada sharing ide-ide bagaimana cara mengahadapi berbagai masalah dalam proses belajar mengajar". 
(in the MGMP forum, the members got knowledge and information that was very useful from the activities held and the information provided.

In the MGMP, also often share ideas on how to deal with various problems in the teaching and learning process) (appendix 3). In terms of contributing to the development of pedagogical competence, she mentioned that there were several MGMP programs related to making lesson plans. So each school is given a task of making lesson plan, then the results are collected and shared in all schools, so there is a common perception among vocational English teachers. Furthermore, she said that as long as she participated in the activities in the MGMP, she felt that she could be more focused in teaching and learning practice. Moreover, she hopes that the quantity of meetings in the MGMP can be increased.

\section{Teacher $F$}

The teacher felt that the MGMP contributed enough to the development of teacher pedagogical competence. He said "MGMP cukup berperan dalam pengembangan pedagogik guru dengan sering mengundang pemateri-pemateri dari luar, baik dari kalangan dosen maupun para ahli yang terkoneksi dengan pembelajaran Bahasa Inggris". (MGMP has a significant role in developing teacher pedagogical competence by often inviting external speakers, both from lecturers and experts who are connected to English learning). He also said that there were many benefits when participating in the MGMP activities in competency development. For example, at the beginning of the school year, the MGMP usually discussed about lesson plan. So each school is distributed basic competencies (KD), and then made the lesson plan. From so many benefits that teachers can get when participating in MGMP activities, he regrets that not all English teachers can attend. This is because most English teachers have other activities at school so they cannot attend in the MGMP forum.

\section{Teacher $G$}

The teacher felt that the contribution of the MGMP forum is very good for the development of teacher competence because before the covid-19 pandemic

\section{Haliza}


there were always held a meeting every month. He said that at the MGMP they often share many things, not only about pedagogical competence. The activities of the development of teachers' pedagogical competence such as designing learning, for example, what method is suitable for a topic or material. He mentioned that a topic about descriptive text for example, then there was a teacher who can use a suitable method with the topic or material, so they share like that. Thus, from sharing things like that, it can add new knowledge and of course develop competences, not only pedagogical competence.

Moreover, he felt that the MGMP provided many benefits to teachers in developing their pedagogical competence. Because in the MGMP they share and receive input from other teachers, of course their competence will develop.

\section{Discussion}

This section presents the discussion of the research finding from interview and documentation with the theories collected in chapter two about the contribution of English Subject Teachers' Working Group (MGMP) in developing teachers' pedagogical competence and the teachers' perception on that contribution.

\section{The Contribution of English Subject Teachers' Working Group (MGMP) in Developing Teachers' Pedagogical Competence}

From the facts of the findings described above, the English MGMP of Vocational High School Kota Banjarmasin provided an excellent contribution to the development of teachers' pedagogical competence. The contribution was provided through the following activities: (1) Sharing material on how to make learning module. (2) Sharing material from the finalist of Olimpiade Guru Nasional (OGN). (3) sharing how to make ICT-Based learning media. (4) Sharing of making soal USBN and sharing teaching strategies. (5) Sharing pragmatics in English language teaching. (6) Making core competencies (KI) and basic competencies (KD) analysis and lesson plan of 2013 curriculum 2017 revision. This statement in line with the MGMP guidelines (Depdiknas, 2004), MGMP must carry out activities to achieve the goals of MGMP include: (1) Improving curriculum 
understanding. (2) Developing a syllabus and assessment system. (3) Developing and design teaching materials. (4) Increasing understanding of Broad based Education and life skills. (5) Developing an effective learning model. (6) Developing and implement making simple learning tools. (7) Developing and implement computer-based learning programs. (8) Developing media in implementing teaching and learning process. The statement above related to what the researcher found when conducting interviews. Almost all teachers or members of the MGMP said that when they participated in the MGMP activities, they always gained new knowledge. Because MGMP often collaborated with several universities and presented resource persons who have expertise in providing material in each activity.

In addition, the administrators and members often share about their teaching experiences, knowledge they got from seminars, training or other experiences. This is in line with Sutrisno (2009), MGMP is an association or assemblage for subject teachers in a studio, regency/city that functions as a means of communicating, learning, and exchanging ideas and experiences in order to improve the performance of teachers as practitioners /subjects of change in the reorientation of learning in the classroom. This statement similarities from what the researcher found when do the interview with the respondents.

Thus, MGMP greatly contributes to developing teachers' competencies by providing programs and activities according to the teachers' needs. The MGMP contributed to making changes to the learning process, provides training for teachers, as well as a place to exchange ideas and also provide solutions to its members if there are problems faced. So, the MGMP forum can contribute and make teachers more professional in accordance with the demands of the times.

The English Teachers' Perception on The Contribution of English Subject Teachers' Working Group (MGMP) in Developing Teachers' Pedagogical Competence 
Based on the finding results, the teachers' perception on the contribution of the MGMP it can be seen those programs or activities in MGMP greatly contribute to the development of teachers' competencies. This is in accordance with Mushfah (2011), the efforts to develop teacher competencies explained by the Directorate General of Primary and Secondary Education of the Ministry of National Education, among others: (a) a program to improve teacher education qualifications, (b) an equalization and certification program, (c) an integrated competency-based training program, (d) an education supervision program, (e) Subject Teacher Working Group (MGMP) empowerment program, (f) Teacher Symposium, (g) other traditional training programs, (h) reading and writing journals of scientific papers, (i) participating in scientific meetings, (j) conducting classroom action research, (k) internships, (l) follow the actual news from the news media, (m) participate and be active in professional organizations, and (n) collaborating with colleagues. MGMP as a community gave a lot of contribution to teachers in developing their competence, be it pedagogical, professional, personal, or social competence, if teachers can actively attend in every routine meeting.

The result of the interview showed that the teachers gave positive perception related to the contribution of MGMP. Most teachers said that through the MGMP forum, they can help each other and share knowledge, experiences, and new ideas. This statement is in line with Jalal (2005) who states that MGMP is a place for collaborative teachers to gather in a certain area (Regency/City) in order to identify and solve problems, try and develop new ideas in order to improve the quality of learning. In addition, a variety of knowledge, experience, and training will be obtained to improve teacher motivation. Furthermore, this forum is believed to be one of the effective media to foster teacher professionalism within the framework of activities by, from and for teachers.

Besides, in the MGMP forum there were many programs and activities that can help teachers solve their problems and develop their competences. It is as what Leu (2004) and Villegas-Reimer (2003) mentioned that teachers' working groups 
are used by some countries as means of professional support for teachers and bring teachers together to address their work problems.

In conclusion to all the aspects of the discussion, the researcher can conclude that the participation of teacher and supported by varied MGMP programs and activities are factors that make the MGMP forum can contribute in developing teachers' pedagogical competence. With the involvement of teachers in the MGMP Forum, it will have a good impact on their performance in managing the learning process in the classroom later.

\section{CONCLUSIONS AND SUGGESTIONS}

The contribution of English Subject Teachers' Working Group (MGMP) in developing teachers' pedagogical competence was carried out by involving various parties and providing various programs and activities. The English MGMP of Vocational High School Kota Banjarmasin usually collaborated with several universities and presented resource persons. The resource person can be from lecturers of the universities, the parties from Dinas Pendidikan dan Kebudayaan Provinsi Kalimantan Selatan, and even from the administrators and the members of the English MGMP. While the contribution of English MGMP provided through the MGMP programs and activities included: (1) Sharing material on how to make learning module. (2) Sharing material from the finalist of Olimpiade Guru Nasional (OGN). (3) sharing how to make ICT-Based learning media. (4) Sharing of making soal USBN and sharing teaching strategies. (5) Sharing pragmatics in English language teaching. (6) Making core competencies (KI) and basic competencies (KD) analysis and lesson plan of 2013 curriculum 2017 revision.

All of English teachers had positive perception on the contribution of English MGMP in developing teachers' pedagogical competence. They felt that the MGMP as a community gave a lot of contribution to teachers in develoving their competencies. Because, it can be seen from the benefits they got when active participating in every activity in the MGMP forum. Through MGMP activities, teachers can discuss to solve all the problems they face, communicate with each

\section{Haliza}


other, consult and exchange experiences, with the result that it can make a contribution in order to improve their performance so that the quality of learning in schools will be better.

The MGMP administrators must cooperate in providing awareness for English teachers because teachers have an obligation to take part in the activities carried out by the MGMP to improve the teacher's abilities. Specifically, it can be carried out by providing counseling during the activity in order to explain and remind the English teachers.

The MGMP activities are expected to be held regularly once a month even though carried out through online meetings due to the Covid-19 pandemic. Given that during this pandemic, teaching and learning activities were carried out online, of course there were many obstacles faced by teachers in providing learning to students. Such as how to apply techniques, strategies, and teaching methods that are appropriate to students. For this reason, these various obstacles should be an important discussion in the MGMP forum.

At the end of the semester it is expected that the MGMP forum will evaluate the activities that have been carried out. So that in the future MGMP can further improve the quality of its activities. It is hoped that teachers will always be active in every MGMP activity by providing motivation and helping each other. It is intended that teachers always develop their potential so that they can achieve the goals of learning more effectively and efficiently.

\section{REFERENCES}

Ada, J. H., \& Azisah, S. (2016). The Contribution of Teachers Pedagogical Competence Toward The Effectiveness of Teaching of English At MTsn Balang-Balang. 2(2), 238-251.

Anugerahwati, M., Saukah, A. (2010). Professional Competence of English Teachers In Indonesia: A Profile of Exemplary Teachers. Indonesian Journal of English Language Teaching, 6(2), 47-59. Retrieved from http://ojs.atmajaya.ac.id/index.php/ijelt/article/view/170.

Creswell, J.W. (2011). Educational Research: Planning, Conducting and Evaluating Quantitative and Qualitative Research. Boston: Pearson. 
Depdiknas. (2004) .Pedoman MGMP.Jakarta: Direktorat Jenderal Pendidikan Dasar Dan Menengah.

Emiliasari, R. N. (2018). An Analysis of Teachers Pedagogical Competence in Lesson Study of MGMP SMP Majalenka. ELTIN Journal, 6(1), 22-33.

Hakim, A. (2015). Contribution of Competence Teacher (Pedagogical, Personality, Professional Competence and Social) On the Performance of Learning. The International Journal Of Engineering And Science (IJES). 4(2), 01-12.

Hendayana, S. et al. (2006). Lesson Study, Suatu Strategi untuk Meningkatkan Keprofesionalan Pendidik (Pengalaman IMSTEP-JICA). Bandung: UPI Press.

Idris M., \& Marno. (2010). Strategi dan Metode Pengajaran: Menciptakan Keterampilan Mengajar yang Efektif dan Edukatif. Yogyakarta: Ar-Ruzz Media.

Jalal, F. (2005). Teachers quality improvement in Indonesia: New Paradigm and milestones. Jakarta: Departemen Pendidikan Nasional.

Maxwell, J. A. (1996). Qualitative Research Design. CaliforniaBeverly Hills:By Sage Publication

Moleong, L. J. (2004). Metodologi Penelitian Kualitatif. Bandung: PT. Remaja Rosdakarya.

Mushfah, J. (2011). Peningkatan Kompetensi Guru Melalui Pelatihan dan Sumber Belajar Teori dan Praktik, (p. 127). Jakarta: Kencana.

Mulatsih, W. (2016). Peran Musyawarah Guru Mata Pelajaran (MGMP) dalam Meningkatkan Kompetensi Pedagogik Guru Pendidikan Pancasila dan Kewarganegaraan SMA di Kabupaten Pekalongan. Skripsi. Jurusan Politik dan Kewarganegaraan. Fakultas Ilmu Sosial, Universitas Negeri Semarang.

Nuraida, N., Nurteti, L. (2018). Konsep Profesionalisme Guru Menurut Alquran Surat Al-Baqarah Ayat 247 (Studi Analisis terhadap Tafsir Ibnu Katsir). Tarbiyat al-Aulad : Jurnal Pendidikan Islam Anak Usia Dini, [S.l.],1(1), ISSN 2549-4651. Retrieved from http://risetiaid.net/index.php/TA/article/view/99.

Permatasari, A. N., Burhanuddin, \& Sobri, A. Y. (2016). Efektivitas Kegiatan Musyawarah Guru Mata Pelajaran dan Pengaruhnya Terhadap Kinerja Guru Di SMP Se-Kecamatan Pandaan Kabupaten Pasuruan. Retrieved from http://ap.fip.um.ac.id/wp-content/uploads/2016/11/aprilia-nia.

Purnomo, M. T. (2015). Hubungan Keikutsertaan Guru dalam MGMP Bahasa Inggris dengan Kompetensi Profesional Guru Mata Pelajaran Bahasa Inggris SMP/MTs Se-Kecamatan Purwakarta. Skripsi. Jurusan Administrasi Pendidikan. Fakultas Ilmu Pendidikann, Universitas Negeri Yogyakarta. 
Rahman, A., Basri, S., \& Mahrum, M. (2016). Exploring Teachers' Perception on Their Participation in Subject Matter Teacher Group. Bahasantodea, 4(3), 9-19.

Rodhi. (2015). The Capacity of English Subject Teachers' Working Group (MGMP) In Supporting Teacher Professional Development: (A Case Study of English MGMP of Senior High Schools in Kota Banjarmasin). Jurnal Pendidikan Bahasa. 4(1):146.

Saifudin, A. (2001), Metode Penelitian Pendidikan. Yogyakarta: Pustaka Belajar.

Sobur, Alex. (2003). Psikologi Umum Dalam Lintasan Sejarah. First edition, Bandung:CV Pustaka Setia.

Sugiono. (2014). Metode Peneitian Kuantitatif Kualitatif dan $R \&$ D. Bandung: Alphabeta.

Tedjawati, J. M. (2011). Peningkatan Kompetensi Guru melalui Lesson Study: Kasus di Kabupaten Bantul. Jurnal Pendidikan dan Kebudayaan, 17(4):480

Undang-Undang Republik Indonesia Nomor 14, Tahun 2005 tentang Guru dan Dosen

Yasin, A. F. (2011). Pengembangan Kompetensi Pedagogik Guru PAI di Madrasah: Studi Kasus di MIN Malang I. Jurnal eL-QUDWAH. 1(5), 157-181 